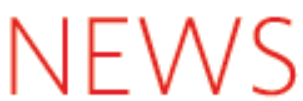

\author{
IMAGE \\ UNAVAILABLE \\ FOR COPYRIGHT \\ REASONS
}

Deadly plan: the four London bombers arrive at Lutonstation on their way to the capital's tube network.

\title{
Psychologists warn of more suicide attacks in the wake of London bombs
}

\section{LONDON}

When bombers struck London on the morning of $7 \mathrm{July}$, the city's inhabitants were shocked but not surprised. Since the 11 September attacks in New York, intelligence officials had warned that Britain's capital was a terrorist target. The real surprise came five days later, when police said that they believed the attacks were the work of suicide bombers. The perpetrators were born and brought up in Britain, had normal jobs and - to their neighbours and colleagues at least - had not seemed to be involved with extremist groups.

But to academics who have studied the psychology of suicide bombers and the groups that back them, this was par for the course. Through interviews with bombers who have failed to detonate their devices, and discussions with the families of those who succeeded, reasonable knowledge about suicide terrorism has been accumulated.

From the West Bank to Iraq to Chechnya, studies have shown that - contrary to media portrayals - economic status, educational background and religious beliefs are not significant factors in motivating the bombers. The attackers are often educated and come

from middle-class backgrounds. They are not suicidal in the typical sense, or even depressed.

"It appears that the London bombers fit the profile of suicide bombers more generally in that there is no profile," says Alan Krueger, an economist at Princeton University in New Jersey who studies terrorism. "Suicide bombers come from all walks of life."

\section{Intentional act}

Intelligence officers in London are reported to be considering whether the bombers intended to blow themselves up, or could have been duped by terrorist organizers into doing so. If the attackers are confirmed as suicide bombers, Krueger and others say that those investigating the attack — and attempting to prevent a repeat - should ignore the personality of the bombers and focus on the politics of local communities and of terrorist organizations.

Ariel Merari, a psychologist at Tel Aviv University in Israel,

"Logic drives their actions. They're not madmen, they're just playing to a different rule book." has met many thwarted suicide bombers over the past 25 years. His studies show that until now, suicide terrorists have tended to emerge from societies that back such actions. Many Palestinians, for example, see what they call 'martyrdom' as a legitimate response to the Israeli occupation.

This assent creates volunteers for the second essential ingredient in suicide terrorism: an organization to support the individual attacker. Once involved with these groups, would-be bombers find it difficult to back out without losing face. Some Islamic organizations lock volunteers in by drawing on their faith and the promise of the afterlife, but religion is not always involved. During the Second World War, for example, Japanese military officials used peer pressure and nationalistic pride to persuade pilots to carry out kamikaze missions.

What about the likelihood of further attacks? Robert Pape, an international-relations specialist at the University of Chicago who has studied data on suicide bombings covering two decades, says that the inhabitants of Western cities should brace themselves. He believes that details of the London bombings, including the use of local people who weren't viewed as key 
terror suspects, look similar to other attacks linked to al-Qaeda, such as the Bali bombings of 2002. That campaign will continue as the group attempts to oust US troops from the Middle East, says Pape.

But Merari believes there will be no largescale campaign of the type seen in Iraq and Israel. "The London bombers do not represent the sentiments of their community," he explains. This lack of support makes it harder for terrorist groups to recruit and easier for police to gather information on suspects. As the group leaders usually have to operate from abroad, it also increases the time needed to plan an attack. "This doesn't mean that more attacks will not occur," says Merari. "But there will not be a wave of them.

\section{Calculated risk}

Andrew Coburn, director of terrorism research for Risk Management Solutions in Cambridge, UK, uses risk-analysis techniques borrowed from the fields of economics and natural disasters to predict terrorist risk for insurance companies. Understanding that the attackers are, in a sense, sane and rational is key to predicting where they might strike and what damage they will inflict, he says.

"Logic drives their actions," he says. "They're not madmen. They're just playing to a different rule book."

Coburn and his colleagues have developed a terrorism risk model that scores different attacks on the basis of how easy they are to carry out versus how much damage they will inflict - not only in terms of human life, but also in economics and the symbolic value of the target.

"It doesn't predict where attacks will happen, but it suggests the kinds of targets," says Coburn. "There are not many locations in the world where you can guarantee 100 people within four metres of your explosion in one of the least welldefended areas, such as a tube train."

Coburn believes that, after an initial period of particularly high security, when the danger is seen as diminished, the risk to London will remain high for years to come. He does not rule out the possibility of terrorists attempting a far larger attack that, although more difficult to pull off, could claim far more lives than the 56 who perished earlier this month.

This was Western Europe's first suicide attack, and Coburn also sees that trend moving gradually westwards. "The risk is spreading from the Middle East, through Europe and into the United States, he says. But he maintains that London can pull off a safe Olympic Gamesin 2012. "When we go all out and crank up the protection for an event, people tend not to attack"

Jim Giles and Michael Hopkin

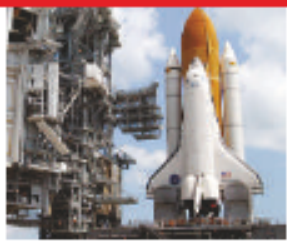

NASA'S DISCOVERY SHUTTLE GROUNDED Faulty fuel sensor puts launch on hold. Read all about the mission online. www.nature.com/news

\section{Altered embryos offered as solution to stem-cell rift}

\section{WASHINGTON DC}

US lawmakers were last week gathering support for legislation that would ease federal restrictions on funding for embryonic stem-cell research.

Public polls favour the bill, which passed by a large bipartisan majority in the House of Representatives on 24 May (see Nature 435, 544-545; 2005). But President George W. Bush is dead against it. That left many senators in the Republican party in a quandary: how could they back a popular measure without alienating pro-life voters and the US president?

Into this fray stepped William Hurlbut, a consulting professor in human biology at Stanford University who serves on the President's Council on Bioethics. At a Senate hearing on 12 July, Hurlbut told lawmakers to back research into the creation of embryo-like entities that have been engineered to lack the capacity to develop into human babies, for example by mutating certain genes.

Hurlbut has proposed that scientists create these entities in a process he calls "altered nuclear transfer", to distinguish it from somatic cell nuclear transfer, which scientists use to create human embryos from which stem cells can be extracted.

Such entities lack the moral status of human embryos, argues Hurlbut, and so could be used for research with fewer ethical objections. "We should find a way to go forward with our biomedical research that gathers in our whole nation," he told the Senate.

Although Hurlbut sees himself as a unifying force, many stem-cell researchers are worried. His proposal has not been tested, and the idea of purposely creating defective embryos has met with serious objections from ethicists.

But it is a gift for politicians who are undecided about stem-cell research. Senate leaders, encouraged by the White House, have begun pushing for laws backing such alternatives to embryonic stem-cell research. The proposals threaten to erode support for the measure to loosen funding restrictions on stem-cell research itself.

Despite opposing the use of embryos for stem-cell research, Hurlbut describes himself as "very pro-science". He attended
IMAGE UNAVAILABLE FOR COPYRIGHT REASONS

William Hur lbut believes embryo-like entities offer a way forward for stem-cell research.

Stanford Medical School, but abandoned plans to practise medicine when his first child was born with severe brain damage.

As a result, Hurlbut decided to devote his career to teaching and studying the ethics of biomedicine. One of his heroes became Saint Francis of Assisi, whose life of poverty was characterized by a love of nature. "I thought, this is exactly what the world needs right now," Hurlbut says. "We were ravaging the natural world, and it was obvious that we were ramping up to ravage and reorder the human body as well."

Joining the President's Council on Bioethics in 2002, Hurlbut says he felt torn between the supporters and opponents of embryonic stem-cell research, and proposed altered nuclear transfer as a way to bridge the divide.

He warns that the debate over stem cells could be the first of a series of battles over the use of powerful techniques in developmental biology. He believes scientists must forge harmony with their opponents or risklosing support and funding for their work.

"If we don't have a solid frame from which we can go forward, there's just going to be an endless series of bitter

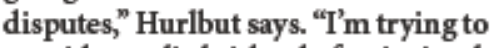
provide one little island of unity in a large sea of controversy."

As Nature went to press, negotiators were still trying to decide how to bring the stem-cell legislation before the full Senate for a vote this week.

Erika Check 